\title{
Naturalistyczna muzykologia systematyczna wobec poglądów Meyera na emocje i znaczenie w muzyce
}

\section{WPROWADZENIE}

W roku 1956 nakładem University of Chicago Press ukazała się po raz pierwszy książka Leonarda B. Meyera pod odważnym i obiecującym tytułem ${ }^{1}$ Emocja $i$ znaczenie $w$ muzyce ${ }^{2}$. Meyer wyłożył w niej swoją, jak się niebawem okazało, doniosłą w skutkach teorię, która wyjaśniać miała w sposób wyczerpujący specyfikę emocjonalnego przeżycia muzycznego. Doniosłość tej pracy dla różnych gałęzi muzykologii, przede wszystkim teorii muzyki i psychologii muzyki ${ }^{3}$, ale też edukacji muzycznej ${ }^{4}$, podkreślana jest dziś przez licznych badaczy, a Meyer określany jest często mianem jednego z głównych dwudziestowiecznych myślicieli podejmujących zagadnienia muzyki Zachodu ${ }^{5}$. John Sloboda przyrównał nawet rolę Meyera w przekształceniu naukowego sposobu myślenia o muzyce do

1 Książka Meyera ukazała się w języku polskim w roku 1973 nakładem Polskiego Wydawnictwa Muzycznego; L.B. Meyer, Emocja i znaczenie w muzyce, przeł. A. Buchner i K. Berger, Kraków 1973.

2 L.B. Meyer, Emotion and Meaning in Music, Chicago 1956.

3 L.L. Cuddy, Tributes to Leonard B. Meyer: Editor's Introduction, „Music Perception: An Interdisciplinary Journal” 2008 t. $25 \mathrm{nr}$ 5, s. 477.

4 Por. np. N. Bannan, Every Child a Composer: Music Education in an Evolutionary Perspective, Bern-New York 2019, s. 19.

5 A. Ockelford, Comparing Notes: How We Make Sense of Music, London 2018, s. 10 roli, jaką odegrał Noam Chomsky w kształtowaniu sposobu rozumienia tego, czym jest język naturalny ${ }^{6}$.

Zasadniczą tezę książki Emocja i znaczenie w muzyce można streścić stwierdzeniem, że przeżycie emocjonalne słuchacza, będące, zdaniem Meyera, jednym z nieodłącznych rodzajów znaczenia muzyki, jest skutkiem spełniania lub niespełniania oczekiwań co do struktury przebiegu muzycznego. Oczekiwania, o których mówi Meyer, są „[...] wynikiem reakcji nawykowych, wykształconych w związku z określonymi stylami muzycznymi, oraz sposobów ludzkiej percepcji, poznania i reakcji [...]"7. Skoro tak twierdzi Meyer, to, zakładając istnienie kompetentnego, czyli znającego określony styl muzyczny słuchacza, można poprzez ogląd struktury samej muzyki „[...] podjąć badanie i analizę zawartości afektywnej określonego dzieła, w tym stylu bez ustawicznego i jawnego odwoływania się do reakcji słuchacza [...]"8. Tak sformułowane postulaty, które Meyer rozwijał w dalszych latach ${ }^{9}$, wskazują jasno na jego ambicje, aby propozycja ta stała się podstawą dla muzykologii

6 J.A. Sloboda, Leonard Meyer: Embracing Uncertainty, „Music Perception: An Interdisciplinary Journal” 2008 t. 25 nr 5, s. 489-491.

7 L.B. Meyer, Emocja..., op. cit., s. 45.

8 Ibidem, s. 47

9 Por. np. L.B. Meyer, Explaining Music: Essays and Explorations, Berkeley-Los Angeles 1973. 
analitycznej i pozwoliła rozwiązać problem obiektywizacji narzędzi analizy afektywnej, skądinąd bazujących zwykle na subiektywnych odczuciach muzykologów co do zawartości emocjonalnej przebiegu muzycznego. Dziś, poszukując źródeł idei głoszącej, że teoria muzyki i analiza muzyczna powinny być pojmowane w kategoriach psychologicznych, wskazujemy zwykle na refleksje wcześniejsze o całe stulecia od propozycji Meyera. Jednak w latach siedemdziesiątych dwudziestego wieku ${ }^{10}$, a już na pewno w latach publikacji Emocji i znaczenia, to właśnie idee Meyera były główną inspiracją dla rozwoju tzw. psychologicznych metod analizy muzycznej ${ }^{11}$.

\section{REAKCJA NA EMOCJĘ I ZNACZENIE W MUZYCE}

Zaraz po publikacji książka Emocja i znaczenie w muzyce spotkała się z szerokim zainteresowaniem przedstawicieli różnych subdyscyplin muzykologicznych. Co ciekawe, zainteresowanie to nie ograniczało się do środowisk skupionych na, szeroko dyskutowanej i obrosłej w niezliczone już wówczas studia i rozprawy, problematyce znaczenia muzyki ${ }^{12}$. Książka wzbudziła bowiem duże zainteresowanie także wśród psychologów ${ }^{13}$ oraz badaczy uprawiających rodzacą się antropologię kulturową ${ }^{14}$. O ile wśród głosów teoretyków muzyki odnaleźć można było, zrozumiałą w tamtych czasach, krytykę wykorzystania przez Meyera wiedzy przyrodniczej do wyjaśniania zjawisk estetycznych ${ }^{15}$, o tyle zarówno w reakcji niektórych psychologów, jak i antropologów kulturowych, interdyscyplinarne podejście Meyera spotkało się z dużym uznaniem.

${ }^{10}$ F. Lerdahl, Reflections on Leonard Meyer, ,Music Perception: An Interdisciplinary Journal" 2008 t. 25 nr 5, s. 483-484.

${ }^{11}$ Por. N. Cook, Przewodnik po analizie muzycznej, przeł. S. Będkowski, Kraków 2014; J. Dunsby, A. Whittall, Music Analysis in Theory and Practice, New Haven 1988, s. 94-99; V. Byros, Meyer's Anvil: Revisiting the Schema Concept, „Music Analysis” 2012 t. 31, s. 273-346.

12 L.P. Beveridge, Review: Emotion and Meaning in Music by Leonard B. Meyer, „The Christian Scholar” 1958 t. 41, s. 175-178.

${ }_{13}$ J.D. Ketchum, Review of Emotion and Meaning in Music, „Canadian Journal of Psychology/Revue canadienne de psychologie” 1957 t. $11 \mathrm{nr} 4$, s. 264-266.

${ }^{14}$ D.P. McAllester, Emotion and Meaning in Music. Leonard B. Meyer, „American Anthropologist” 1957 t. 59 nr 5, s. 940.

${ }^{15}$ L.P. Beveridge, Review..., op. cit.
Ketchum pisał na przykład we wstępie do swojej recenzji książki Meyera ${ }^{16}$, że „[...] zastosowanie pewnych naszych [psychologów] teorii do jego [Meyera] własnego obszaru ujawnia $\mathrm{w}$ nich moc wyjaśniającą, którą niewielu z nas rozpoznało" ${ }^{17}$, a McAllester stwierdzi1 $^{18}$, iż „[...] Leonard Meyer napisał antropologię muzyki zanim uczynili to antropolodzy"19. Warto podkreślić, że Meyer tworzył swoją teorię, zainspirowaną osiągnięciami gestaltyzmu i teorii informacji, w obliczu braku niemal jakichkolwiek badań empirycznych nad rolą oczekiwań muzycznych w powstawaniu doświadczeń emocjonalnych słuchaczy. Praca Meyera jest zatem dobrym przykładem spekulacji teoretycznych, które opierają się z jednej strony na odkryciach przyrodniczych $\mathrm{w}$ domenie ogólnych zasad poznania człowieka, a z drugiej dają szerokie możliwości empirycznej weryfikacji poczynionych założeń odnoszących się do wybranego, wąskiego obszaru wiedzy. Obszarem tym jest w tym przypadku doświadczenie emocjonalne muzyki i jej znaczenie.

\section{IDEE MEYERA A BADANIA EKSPERYMENTALNE}

Meyer nie zwrócił się w kierunku empirycznych badań z zakresu psychologii eksperymentalnej celem weryfikacji swoich twierdzeń. Wykorzystał te twierdzenia raczej jako podstawę dla dalszych rozważań $\mathrm{w}$ domenie tradycyjnie rozumianej estetyki muzyki $i$ analizy muzycznej ${ }^{20}$. Wielu badaczy zainspirowanych koncepcją Meyera podjęło jednak wysiłki eksperymentalnego sprawdzenia jego postulatów. Być może

${ }^{16}$ J.D. Ketchum, Review..., op. cit.

17, „...] applying some of our theories to his own [Meyer's] field, reveals in them explanatory powers which few of us have recognized"; ibidem, s. 264.

${ }^{18}$ D.P. McAllester, Emotion..., op. cit.

19 „[...] Leonard Meyer has written an anthropology of music before the anthropologists have", ibidem, s. 940.

${ }^{20}$ Jak ujmuje to zręcznie Esther Dunsby „If Meyer's model for musical perception given in Emotion and Meaning underlies the argument of his later books, Music, the Arts, and Ideas is its aesthetic expression and Explaining Music is its technical realization" (Jeśli model percepcji muzyki Meyera wyłożony w Emocji $i$ znaczeniu $w$ muzyce stanowi podłoże dla argumentacji jego późniejszych książek, to Music, the Arts, and Ideas jest jego [meyerowskiego modelu percepcji] wyrazem estetycznym a Explaining Music jego realizacją techniczną); E. Dunsby, Explaining Meyer, „Music Analysis” 1983 t. 2 nr 2, s. 211 
postawa Meyera w tym względzie wynikała $\mathrm{z}$ różnic pomiędzy ówczesnym „stylem uprawiania humanistyki i nauk przyrodniczych", który dość dobrze obrazuje anegdotyczna uwaga Meyera skierowana do Carol Krumhansl. Na usilne prośby Krumhansl o komentarz do jej prac eksperymentalnych inspirowanych jego postulatami Meyer miał odpowiedzieć, że rozumie pojęcie „prawdopodobieństwa” $\mathrm{w}$ inny sposób ${ }^{21}$. Nie wiadomo, co Meyer miał dokładnie na myśli, ale być może była to po prostu próba odniesienia się z rezerwą do frazeologii przyrodniczej. Nie znaczy to jednak, że Meyer dystansował się całkowicie od eksperymentalnych prac badawczych uprawianych na podstawie jego postulatów. Przykładem takiego zainteresowania jest chociażby to, że Meyer uczestniczył aktywnie w konferencjach Society for Music Perception and Cognition i był współzałożycielem jednego z najważniejszych czasopism naukowych poświęconych zagadnieniom percepcji muzyki - „Music Perception: An Interdisciplinary Journal"22. Meyer jest też autorem rozdziału w pracy zbiorowej z 2001 roku $^{23}$ poświęconej muzyce i emocjom $^{24}$, która stanowi próbę przedstawienia możliwie szerokiego, wielodyscyplinowego spektrum ówczesnej wiedzy o związkach muzyki z emocjami. Osiągnięcia interdyscyplinarnych badań nad muzyką i emocjami, uwzględniające postulaty Meyera, zaczęły oddziaływać później także na muzykologię analityczną ${ }^{25}$. Innym ważnym obszarem wpływu pracy Meyera z 1956 roku na refleksję muzykologiczną są wszelkie koncepcje teoretyczne, bazujące na założeniach gestalty$\mathrm{zmu}^{26}$. Według Patrika Juslina to właśnie wykorzystanie

${ }^{21}$ C.L. Krumhansl, Leonard Meyer's Invitation to Cognitive Science, „Music Perception: An Interdisciplinary Journal” 2008 t. 25 nr 5, s. 483 .

${ }^{22}$ L.L. Cuddy, Tributes..., op. cit.

${ }^{23}$ Rozdział ten jest pokłosiem wykładu plenarnego, jaki Meyer wygłosił w lipcu 2001 roku na konferencji organizowanej przez Society for Music Perception and Cognition, która odbyła się na Queens University w Kingston, Ontario.

${ }^{24}$ L.B. Meyer, Music and Emotion: Distinction and Uncertainties, [w:] Music and Emotion: Theory and Research, red. P.N. Juslin, J.A. Sloboda, „Series in Affective Science”, Oxford 2001, s. 341-360.

${ }^{25}$ E.H. Margulis, Surprise and Listening Ahead: Analytic Engagements with Musical Tendencies, „Music Theory Spectrum” 2007 t. 29 nr 2, s. 197-217.

${ }^{26}$ F. Lerdahl, R. Jackendoff, A Generative Theory of Tonal Music, Cambridge, MA-London 1983; E. Narmour, The Analysis and Cognition of Basic Melodic Structures: The Implication-Realization Model, Chicago 1990; D. Temperley, The Cognition of Basic Musical Structures, Cambridge, MA-London 2001 przez Meyera gestaltyzmu było w muzykologii pierwszym skutecznym podejściem $\mathrm{w}$ analizie reakcji emocjonalnej na muzykę $e^{27}$. Meyer był niewątpliwie pionierem zastosowania gestaltyzmu w muzykologii ${ }^{28}$, a biorąc pod uwagę rosnące znaczenie badań nad percepcją muzyki w muzykologii systematycznej, w których gestaltyzm jest niewątpliwie jedną z wciąż wpływowych teorii, nie sposób przecenić i tutaj doniosłości oddziaływania rewolucyjnych idei Meyera.

Paradoksalnie więc, bo wbrew estetyczno-teoretycznym ambicjom samego Meyera, wydaje się, iż wpływ postulatów Meyerowskich z Emocji i znaczenia $w$ muzyce na refleksję o muzyce jest najsilniejszy przede wszystkim w muzykologii systematycznej zorientowanej naturalistycznie. Tradycyjnie rozumiane estetyka i teoria muzyki wydają się tymczasem traktować poglądy Meyera jako jedne $\mathrm{z}$ wielu równouprawnionych, choć oczywiście nie da się zaprzeczyć, że także i w tych obszarach refleksji oddziaływanie poglądów Meyera jest zauważalne ${ }^{29}$. Zasadnicza teza pracy Meyera z 1956 roku o roli oczekiwań słuchacza w procesie doświadczenia emocjonalnego muzyki, stając się, z pewnymi dodatkowymi założeniami, podstawą dla dalszych prac eksperymentalnych nad percepcją i doświadczeniem struktury muzycznej, jest obecnie poglądem dominującym wśród psychologów muzyki i muzykologów kognitywnych zajmujących się związkami struktury muzycznej z emocjami. Postulaty Meyera obecne są w wielu współczesnych pracach teoretycznych akceptujących naturalistyczne i kognitywne podstawy dla wyjaśniania poznania muzycznego, zarówno tych powstałych w czasach kształtowania się muzykologii kognitywnej i psychologii poznawczej muzyki ${ }^{30}$, jak i tych najnowszych ${ }^{31}$. Założenia Meyerowskie odnaleźć można także w zaproponowanym przez Cheung i współautorów neurokognitywnym modelu muzycznie wywoływanej przyjemności ${ }^{32}$, którego zakres wykorzystania wykracza

27 P.N. Juslin, Musical Emotions Explained: Unlocking the Secrets of Musical Affect, Oxford 2019, s. 346.

${ }_{28}$ A. Ockelford, Comparing..., op. cit., s. 32.

29 Por. np. V. Byros, Meyer's..., op. cit.

${ }^{30}$ Por. np. J.A. Sloboda, The Musical Mind, Oxford 1986.

${ }_{31}$ Por. np. F. Lerdahl, Composition and Cognition: Reflections on Contemporary Music and the Musical Mind, Oakland 2020.

32 V.K.M. Cheung i in., Uncertainty and Surprise Jointly Predict Musical Pleasure and Amygdala, Hippocampus, and Auditory Cortex Activity, „Current Biology” 2019 t. 29 nr 23, s. 4084-4092.e4. 
daleko poza wąsko rozumianą psychologię muzyki i tworzy interesujące narzędzie dla badań z zakresu tzw. estetyki empirycznej nie tylko muzyki, ale wszelkich innych sztuk czasowych (temporal arts $)^{33}$. O doniosłości tego modelu ${ }^{34}$ dla muzykologii kognitywnej i nauki w ogóle świadczy pojawienie się wzmianki o wynikach badań neuroobrazowych $\mathrm{z}$ wykorzystaniem wspomnianego modelu $\mathrm{w}$ jednym $\mathrm{z}$ prestiżowych czasopism naukowych - „Nature Reviews Neuroscience" ${ }^{35}$. Ugruntowana w zorientowanej naturalistycznie muzykologii systematycznej pozycja Meyera opiera się przede wszystkim na potwierdzonych eksperymentalnie twierdzeniach Meyera o roli naszych oczekiwań w doświadczaniu muzyki.

\section{ROLA PRZEWIDYWAŃ W DOŚWIADCZENIU MUZYKI WEDLUG MEYERA}

Twierdzenie, iż doświadczenie muzyczne jest uwarunkowane naszymi oczekiwaniami wytworzonymi na podstawie wcześniejszego doświadczania muzyki, nie jest bynajmniej wyłącznie introspekcyjnym spostrzeżeniem Meyera. Przeciwnie, Meyer, mówiąc o stosunkach prawdopodobieństwa elementów charakterystycznych dla określonego stylu muzycznego, przywołuje rozważania teoretyczne o muzyce Zarlina i Rameau, ale też analizy muzyki pozaeuropejskiej ${ }^{36}$. Oczywiście ani Zarlino, ani Rameau nie posługiwali się w swych ujęciach teoretycznych kategoriami obecnymi później w dwudziestowiecznej psychologii, czy teorii informacji, do których odwoływał się Meyer. Autor ten chciał jednak zwrócić uwagę na fakt, że liczne dotychczasowe opisy stylistyczne muzyki dają się w prosty sposób ująć w stosunki prawdopodobieństwa, które postulował w Emocji i znaczeniu w muzy$c e^{37}$. Pogląd, że oczekiwania są ważnym elementem

${ }_{33}$ D.B. Huron, Musical Aesthetics: Uncertainty and Surprise Enhance Our Enjoyment of Music, „Current Biology” 2019 t. 29 nr 23, R1238-40.

${ }^{34}$ Więcej informacji o wspomnianym tu modelu znajdzie czytelnik w części zatytułowanej „Niepewność a zaskoczenie”.

35 N. Bray, Musical Pleasure Lies in Surprise, „Nature Reviews Neuroscience" 2020 t. 21 nr 1, s. 3.

36 L.B. Meyer, Emocja..., op. cit., s. 73-74.

37 Ibidem, s. 74-75. doświadczenia muzyki nie jest też oryginalnym spostrzeżeniem Meyera. Na rolę oczekiwań podczas słuchania muzyki wskazywał już chociażby w XIX wieku Hermann von Helmholtz ${ }^{38}$. Niewątpliwie jednak w czasach, gdy Meyer pisał swoją książkę, rola przewidywań i ich naruszeń $\mathrm{w}$ estetyce doświadczenia muzyki nie była wcale oczywista ${ }^{39}$. Według Meyera, dla rozpoznania znaczenia przebiegu muzycznego konieczna jest znajomość przez słuchacza stylu słuchanego przebiegu. Styl muzyczny natomiast, mówiąc najprościej, jest zbiorem prawdopodobieństw, które można opisać w kategoriach teorii informacji. Meyer twierdził mianowicie, że „[...] style muzyczne są zasadniczo złożonymi systemami stosunków prawdopodobieństwa, w których znaczenie jakiegoś ukształtowania lub serii ukształtowań zależy od ich związków z wszystkimi innymi ukształtowaniami, możliwymi $\mathrm{w}$ ramach systemu stylistycznego" ${ }^{40}$. Aby wyjaśnić konsekwencje takiego rozumienia stylu muzycznego dla określenia zawartości informacyjnej muzyki, Meyer odwołał się w sposób precyzyjny do teorii informacji już po publikacji Emocji i znaczenia $w$ muzyce, definiując informację jako miarę przypadkowości (randomness $)^{41}$. W tym ujęciu duże prawdopodobieństwo jakiegoś następstwa dźwięków oznacza jego niską zawartość informacyjną (entropię). Jeśli natomiast jakieś następstwo jest mało prawdopodobne, to jego zawartość informacyjna jest wysoka ${ }^{42}$. Prawdopodobieństwo określonego następstwa dźwięku (grupy dźwięków) jest zatem odwrotnie proporcjonalne do jego zawartości informacyjnej.

\section{PARADOKS TEORII INFORMACJI}

Główny zarzut wobec twierdzenia Meyera, że znaczenie muzyki uwarunkowane jest spełnianiem (bądź nie) naszych oczekiwań co do przebiegu muzycznego,

38 H. von Helmholtz, On the Sensations of Tone as a Physiological Basis for the Theory of Music, przeł. A.J. Ellis, wyd. 3, London-New York 1895, s. 284-285.

39 J.J. Bharucha, Expectation as an Implicit Process, „Music Perception: An Interdisciplinary Journal” 2008 t. 25 nr 5, s. 477-478.

${ }^{40}$ L.B. Meyer, Emocja..., op. cit., s. 73.

41 L.B. Meyer, Meaning in Music and Information Theory, „Journal of Aesthetics \& Art Criticism" 1957 t. 15, s. 412-424.

42 Ibidem, s. 416. 
sformułował Sherburne ${ }^{43}$. Przedstawił on zaskakujący w swej prostocie argument, odwołując się do sytuacji, która określona została później mianem tzw. „paradoksu teorii informacji” ${ }^{44}$, lub „paradoksu Wittgensteina" ${ }^{45}$. Jeśli punktem odniesienia dla rozpoznania znaczenia muzycznego jest tak zwany kompetentny słuchacz, to wspomniane wyżej prawdopodobieństwa następstw dźwięków określane są na podstawie przewidywań tego słuchacza, które z kolei zależą od jego doświadczenia. Po wielokrotnym przesłuchaniu określonego utworu muzycznego oczekiwania kompetentnego słuchacza co do kolejnych dźwięków tego utworu są coraz bardziej jednoznacznie określone. Innymi słowy, ów słuchacz po wielokrotnym wysłuchaniu danego utworu muzycznego dokładnie wie, jaka jest struktura tego utworu i, co za tym idzie, spodziewa się z niemal stuprocentową pewnością kolejnych dźwięków przebiegu muzycznego. Co ważne, przy słuchaniu tego utworu wszystkie oczekiwania takiego kompetentnego słuchacza, przynajmniej te dotyczące struktury muzycznej, są całkowicie spełniane. $Z$ tej perspektywy prawdopodobieństwo następstw poszczególnych dźwięków jest bardzo duże, co oznacza, że ich zawartość informacyjna jest bardzo mała.

Sytuacja ta rodzi dwie kardynalne konsekwencje. Zdają się one $\mathrm{z}$ jednej strony burzyć przekonanie Meyera o możliwości obiektywnej analizy struktury muzycznej w oparciu o jego założenia teoretyczne, a z drugiej przeczyć naszym doświadczeniom. Po pierwsze, pogłębiająca się znajomość danego utworu muzycznego wpływa na jego zawartość informacyjną. Jeśli tak, to nie można mówić o stabilnej zawartości informacyjnej struktury muzycznej, tak jak nie można mówić o jednym, wyidealizowanym, kompetentnym słuchaczu. Po drugie, nasze doświadczenie przebiegu struktury muzycznej powinno zmieniać się znacząco -

${ }_{43}$ D.W. Sherburne, Meaning and Music, „The Journal of Aesthetics and Art Criticism" 1966 t. 24 nr 4, s. 579-583.

${ }_{44}$ Por. J.M. Titchener, M.E. Broyles, Meyer, Meaning, and Music, „The Journal of Aesthetics and Art Criticism” 1973 t. 32 nr 1, s. 17.

${ }_{45}$ Nazwa „paradoks Wittgensteina” ma swoje korzenie w rozważaniach Dowlinga i Harwooda, którzy nawiązali na użytek dyskusji o oczekiwaniach muzycznych (W.J. Dowling, D.L. Harwood, Music Cognition, Orlando, San Diego 1986, s. 220) do przemyśleń Wittgensteina dotyczących efektu wywoływanego słuchaniem konkretnego menueta (L.J.J. Wittgenstein, Lectures and Conversations on Aesthetics, Psychology and Religious Belief, red. C. Barrett, Berkeley, Los Angeles 1967, s. 29), zob. też J.J. Bharucha, Tonality and Expectation, [w:] Musical Perceptions, red. R. Aiello, J.A. Sloboda, New York 1994, s. 215. w pewnym sensie emocjonalnie „wypłaszczać” - wraz z jej coraz lepszą znajomością. Im bardziej bowiem spodziewamy się jakiegoś słuchanego następstwa dźwięków, tym mniejszą reakcję emocjonalną ono powoduje. Wniosek taki, choć logicznie spójny i zgodny z założeniami Meyerowskiej teorii, przeczy w oczywisty sposób naszym doświadczeniom. Mówiąc bardziej obrazowo, kadencja zwodnicza w kantacie Bacha nie staje się w naszym odczuciu mniej „Zwodnicza” po każdym kolejnym wysłuchaniu tej kantaty.

\section{OCZEKIWANIA SCHEMATYCZNE A WEREDYCZNE}

Rozwiązanie tego paradoksu pojawiło się nieoczekiwanie nie na gruncie filozofii czy estetyki muzyki, ale w środowisku psychologów muzyki i wiązało się Z wyróżnieniem dwóch rodzajów przewidywań muzycznych, a mianowicie przewidywań schematycznych (schematic expectancies) i weredycznych (veridical expectancies $)^{46}$. Przewidywania schematyczne to takie, które odwołują się do wyuczonych umysłowych reprezentacji schematycznych, czyli wyodrębnionych typowych relacji pomiędzy elementami przebiegów muzycznych charakterystycznych dla muzyki intensywnie doświadczanej przez daną osobę ${ }^{47}$. Natomiast przewidywania weredyczne to te, które wiążą się z aktywacją reprezentacji umysłowych konkretnego przebiegu muzycznego, na przykład melodii czy następstw akordów lub, jak proponują Schubert i Pearce, łańcucha powiązanych ze sobą fraz ${ }^{48}$. Istnienie tych dwóch rodzajów pamięci wiąże się zatem $\mathrm{z}$ istnieniem dwóch rodzajów magazynów pamięci pamięci schematycznej, w której przechowywane są wzorce stylistyczne o różnym prawdopodobieństwie wystąpienia oraz pamięci weredycznej (dosłownej), składającej się z reprezentacji następstw dźwięków

${ }^{46}$ J.J. Bharucha, Tonality and Expectation..., op. cit.; J.J. Bharucha, Music Cognition and Perceptual Facilitation: A Connectionist Framework, „Music Perception” 1987 t. 5 nr 1, s. 1-30.

${ }^{47}$ J.J. Bharucha, Music Cognition and Perceptual Facilitation..., op. cit.

${ }^{48}$ E. Schubert, M. Pearce, A New Look at Musical Expectancy: The Veridical Versus the General in the Mental Organization of Music, [w:] International Symposium on Computer Music Multidisciplinary Research CMMR 2015: Music, Mind, and Embodiment, red. R. Kronland-Martinet, M. Aramaki, S. Ystad, Cham 2016, s. 358-370. 
dla konkretnych przebiegów muzycznych. Mówiąc obrazowo, wykorzystując magazyn pamięci schematycznej i związane $\mathrm{z}$ nim przewidywania jesteśmy w stanie rozpoznać styl muzyczny, podczas gdy za pomocą pamięci weredycznej rozpoznajemy konkretną melodię czy następstwo akordów. Choć oba te rodzaje przewidywań mogą niekiedy wzajemnie na siebie oddziaływać, stwierdza się ich stosunkową niezależność zaobserwowaną zarówno w badaniach psychologicznych $^{49}$, jak i neuroobrazowych ${ }^{50}$.

Dzięki temu rozróżnieniu łatwo jest obronić słuszność postulatów Meyera, dotyczących zarówno warunku spełniania bądź niespełniania oczekiwań dla powstawania zróżnicowanych reakcji emocjonalnych słuchacza na strukturę muzyczną, jak i twierdzenia o stylu muzycznym jako zbiorze prawdopodobieństw. Zarówno oczekiwania słuchacza, jak i zróżnicowane prawdopodobieństwa wystąpienia poszczególnych elementów struktury muzycznej są rezultatem swoistej poznawczej odrębności magazynu pamięci schematycznej. Jest to możliwe, ponieważ oba rodzaje pamięci pełnią różne funkcje. Pamięć schematyczna jest związana $\mathrm{z}$ uczeniem się regularności występujących $\mathrm{w}$ zmieniającym się permanentnie środowisku i skutecznym radzeniem sobie $\mathrm{z}$ tymi zmianami. Pamięć weredyczna natomiast umożliwia rozpoznawanie konkretnych jednostkowych zjawisk ${ }^{51}$. Z tej perspektywy to właśnie swoistość i odrębność pamięci schematycznej odpowiadają za efekty opisane i postulowane przez Meyera, ponieważ jej zawartość jest tworzona dzięki nieświadomej analizie częstości występowania wszystkich następstw dźwięków w dotychczasowym doświadczeniu muzycznym słuchacza.

49 B. Tillmann, E. Bigand, Musical Structure Processing after Repeated Listening: Schematic Expectations Resist Veridical Expectations, „Musicae Scientiae” 2010 t. 14 nr 2 suppl. (1 September), s. 33-47.

50 S. Guo, S. Koelsch, Effects of Veridical Expectations on Syntax Processing in Music: Event-Related Potential Evidence, „Scientific Reports" 2016 t. 6 nr 1, s. 19064.

51 Wprawdzie rozpoznawanie konkretnych melodii prowadzić może także do reakcji emocjonalnej (por. np. S. Eschrich, T.F. Münte, E.O. Altenmüller, Unforgettable Film Music: The Role of Emotion in Episodic Long-Term Memory for Music, „BMC Neuroscience” 2008 t. $9 \mathrm{nr}$ 1, s. 48), ale reakcja ta następuje wówczas w odpowiedzi na rozpoznanie konkretnych specyficznych wyłącznie dla określonego przebiegu cech i wiąże się $\mathrm{z}$ innymi mechanizmami poznawczymi niż te, które biorą udział w przetwarzaniu napięć i odprężeń podczas doświadczania kolejnych dźwięków struktury muzycznej. Innymi słowy, oczekiwania schematyczne oddziaływają lokalnie, podczas gdy oczekiwania weredyczne globalnie.
Oczekiwania schematyczne natomiast powstają na podstawie nieustannego, również niedostępnego dla naszej świadomości, szacowania prawdopodobieństwa wystąpienia kolejnego dźwięku. Szacowanie to możliwe jest właśnie dlatego, że mamy ów magazyn pamięci schematycznej. Ponieważ częstości występowania następstw dźwięków dla różnych stylów muzycznych są różne, oczekiwania schematyczne pozwalają nam rozpoznawać określony styl muzyczny, pod warunkiem, że wysłuchaliśmy wystarczająco dużo przebiegów muzycznych utrzymanych w tym stylu, aby nasz umysł mógł wytworzyć miarodajne predykcje. $\mathrm{Z}$ tej też przyczyny wspomniana wcześniej kadencja zwodnicza wzbudza w nas odczucia „Zwodzenia”, ponieważ w całym repertuarze muzycznym, którego doświadczyliśmy w naszym życiu, charakterystyczne dla kadencji zwodniczej następstwo toniki VI stopnia po dominancie jest statystycznie dużo rzadsze niż następstwo toniki po dominancie i tym samym tonika VI stopnia jest dla nas mniej oczekiwana po dominancie niż tonika.

\section{ROLA OCZEKIWAŃ W PERCEPCJI MUZYKI}

Okazuje się, że taki predykcyjny sposób rozumienia doświadczenia muzyki wpisuje się nie tylko we współczesne założenia dotyczące tak percepcji muzyki, jak i działania systemu percepcyjnego człowieka w ogóle, ale potwierdzany jest wynikami badań empirycznych nad poznaniem muzycznym ${ }^{52}$. Po pierwsze, twierdzi się dziś, że tworzenie oczekiwań należy do podstawowych funkcji systemów percepcyjnych nie tylko ludzi, ale wszystkich innych zwierząt ${ }^{53}$. Po drugie, za jeden $\mathrm{z}$ podstawowych mechanizmów zdobywania informacji z otaczającego nas świata uważa się tzw. „uczenie się statystyczne” (ang. statistical learning), które obserwowane jest nie tylko u ludzi, ale też, $\mathrm{z}$ uwzględnieniem specyfiki gatunkowej, u innych

52 M.A. Rohrmeier, S. Koelsch, Predictive Information Processing in Music Cognition. A Critical Review, „International Journal of Psychophysiology” 2012 t. 83 nr 2, s. 164-175.; S. Koelsch, P. Vuust, K. Friston, Predictive Processes and the Peculiar Case of Music, „Trends in Cognitive Sciences" 2019 t. 23 nr 1, s. 63-77.

${ }_{53}$ R.R. Llinás, I of the Vortex: From Neurons to Self, Cambridge, MA-London 2001 
gatunków ${ }^{54}$. Mechanizm ten opiera się na nieuświadomionej statystycznej analizie regularności w docierających do naszego systemu poznawczego bodźców i obserwowany jest na niemal każdym etapie przetwarzania informacji w układzie nerwowym. Jak pokazują natomiast liczne modele kognitywne, jedną z kluczowych strategii uczenia się statystycznego jest tzw. wnioskowanie bayesowskie, które polega na nieustannym aktualizowaniu prawdopodobieństwa naszych oczekiwań na podstawie prawdopodobieństwa wcześniejszych (dotychczasowych) oczekiwań $\mathrm{w}$ świetle percypowanych nowych informacji.

Tworzenie reprezentacji schematycznych muzyki za pomocą wnioskowania bayesowskiego polega na realizacji następujących zadań poznawczych. Słuchany przebieg muzyczny poddawany jest $\mathrm{w}$ naszym umyśle nieświadomej analizie częstości występowania poszczególnych następstw dźwięków pod względem wszystkich uchwytnych percepcyjnie parametrów z każdego poziomu przetwarzania informacji dźwiękowej w układzie nerwowym człowieka. Podczas słuchania kolejnego przebiegu muzycznego nasz umysł dokonuje takiej samej analizy oraz porównuje uzyskane wyniki z tymi uzyskanymi w analizie poprzednio słuchanego przebiegu. Na tej podstawie tworzone są mapy częstości występowania wspomnianych parametrów $\mathrm{w}$ dotychczasowo przesłuchanych przebiegach. Proces ten powtarza się tak długo, jak długo działa nasz system percepcyjny, a na podstawie tak zdobywanych danych nasz umysł tworzy oczekiwania. Jak pokazują badania empiryczne, proces uczenia się statystycznego prowadzi do wytwarzania zróżnicowanych przewidywań co do następstw dźwięków, które są powiązane ze specyficznymi wzorcami aktywności neuronalnej ${ }^{55}$. Przewaga statystyczna określonych następstw dźwięków w muzyce charakterystycznej dla kultury, w której żyjemy, powoduje w dłuższej perspektywie czasu, że nasz magazyn pamięci schematycznej wypełniony jest zbiorem najróżniejszych schematów o zróżnicowanych prawdopodobieństwach

54 C. Santolin, J.R. Saffran, Constraints on Statistical Learning Across Species, „Trends in Cognitive Sciences” 2018 t. 22 nr 1, s. 52-63; E.L. Newport i in., Learning at a Distance II. Statistical Learning of Non-Adjacent Dependencies in a Non-Human Primate, „Cognitive Psychology" 2004 t. 49 nr 2, s. 85-117.

55 M.T. Pearce i in., Unsupervised Statistical Learning Underpins Computational, Behavioural, and Neural Manifestations of Musical Expectation, „NeuroImage” 2010 t. 50 nr 1 (March), s. 302-313. ich wystapienia i pozwala nam grupować słuchane przebiegi muzyczne według różnych stylów, jak również dokonywać różnego rodzaju predykcji.

\section{OCZEKIWANIA A SYNTAKTYKA MUZYCZNA}

Jednym z najciekawszych efektów zastosowania tego mechanizmu w percepcji muzyki jest rozpoznawanie reguł organizacji syntaktycznej muzyki. Występowanie regularności w następstwach wysokości dźwięku i akcentacji metrycznej pozwala na intuicyjne, niewymagające żadnej specjalistycznej wiedzy, a jedynie „osłuchania” $z$ danym dialektem muzycznym, rozpoznawanie błędów - swoistych zaburzeń tonalnych, czy odstępstw od organizacji metrycznej przebiegu muzycznego. Rozpoznanie szczególnie rzadkich następstw, jak na przykład tzw. dźwięków obcych w przebiegu tonalnym, może być widoczne $\mathrm{w}$ introspekcji słuchaczy (choć niekiedy nawet rozpoznanie takie nie musi być uświadomione), a także $\mathrm{w}$ markerach somatycznych aktywności autonomicznego układu nerwowego (np. zmianach przewodności elektrycznej skóry) ${ }^{56}$. Mając na uwadze, iż percepcja struktury muzycznej wiąże się z wykorzystaniem, podczas przetwarzania bodźców muzycznych, wnioskowania bayesowskiego, wysiłki części muzykologów kognitywnych skierowane zostały $\mathrm{w}$ stronę prac nad stworzeniem adekwatnego modelu obliczeniowego. Propozycje te dotyczą różnych aspektów przebiegu muzycznego i ujmują Meyerowskie przewidywania w probabilistyczne modele obliczeniowe ${ }^{57}$. Jednym $\mathrm{z}$ efektów tych prac jest możliwość opisania każdego następstwa dźwiękowego w przebiegu muzycznym w kategoriach określonej wartości liczbowej w przedziale od 0 do 1 , gdzie 0 oznacza

56 E.J. Gorzelańczyk i in., Pitch Syntax Violations Are Linked to Greater Skin Conductance Changes, Relative to Timbral Violations The Predictive Role of the Reward System in Perspective of Cortico-Subcortical Loops, „Frontiers in Psychology” 2017 t. 8 (April), s. 586.

57 M.T. Pearce, G.A. Wiggins, Expectation in Melody: The Influence of Context and Learning, „Music Perception: An Interdisciplinary Journal” 2006 t. 23 nr 5, s. 377-405; M.T. Pearce, G.A. Wiggins, Auditory Expectation: The Information Dynamics of Music Perception and Cognition, „Topics in Cognitive Science” 2012 t. 4 nr 4, s. 625652; E. Schubert, M. Pearce, A New Look at Musical Expectancy..., op. cit.; N.Chr. Hansen, M.T. Pearce, Predictive Uncertainty in Auditory Sequence Processing, „Frontiers in Psychology” 2014 t. 5 (September), s. 1052. 
całkowite nieprawdopodobieństwo wystąpienia danego dźwięku, a 1 całkowitą pewnośćjego wystąpienia. Takie ujęcie przebiegu struktury muzycznej jest obecnie powszechnie stosowane $\mathrm{w}$ badaniach psychologicznych, neuropsychologicznych i neurobiologicznych poświęconych różnym aspektom tak samego doświadczenia psychicznego muzyki, jak i szczegółom przetwarzania muzyki w układzie nerwowym człowieka ${ }^{58}$.

\section{„SŁODKIE OCZEKIWANIA” WOBEC IDEI MEYERA}

W roku 2006 ukazuje się praca Davida Hurona pod wymownym tytułem Sweet Anticipation: Music and the Psychology of Expectation [Słodkie oczekiwania: muzyka a psychologia przewidywania $]^{59}$, który nawiązuje bezpośrednio do idei Meyera. Książka Hurona stanowi, czego nie ukrywa sam autor, kontynuację i rozwinięcie koncepcji Meyera wyrażonych w Emocji i znaczeniu w muzyce. Rozwinięcie to polega przede wszystkim na szczegółowym wykazaniu, jak poznawcze mechanizmy predykcyjne warunkują nasze reakcje emocjonalne na zmieniające się pod względem różnych parametrów przebiegi muzyczne, $\mathrm{w}$ świetle aktualnej wiedzy z zakresu kognitywistyki. Innymi słowy, Huron stara się wyjaśnić, jak z perspektywy neurokognitywnej dochodzi do powstawania Meyerowskich oczekiwań i jak oczekiwania te wpływają na zjawiska związane $\mathrm{z}$ percepcją muzyki, które zachodzą w układzie nerwowym człowieka. Głównym celem książki Hurona jest przedstawienie „wyczerpującej teorii przewidywania"60. Autor określa ją akronimem ITPRA, który pochodzi od nazw pięciu odrębnych anatomicznie i funkcjonalnie predykcyjnych systemów poznawczych. Systemy te generują reakcje emocjonalne na słuchany przebieg muzyczny, takie jak: Imagination response [reakcja wyobrażeniowa], Tension response [reakcja napięciotwórcza], Prediction response [reakcja predykcyjna], Reaction response

${ }^{58}$ F.C. Moss i in., Statistical Characteristics of Tonal Harmony: A Corpus Study of Beethoven's String Quartets, „PLOS ONE” 2019 t. 14 nr 6, e0217242; M.T. Pearce, G.A. Wiggins, Expectation in Melody..., op. cit.; M.T. Pearce i in., Unsupervised Statistical Learning..., op. cit.

${ }_{59}$ D.B. Huron, Sweet Anticipation: Music and the Psychology of Expectation, Cambridge, MA-London 2006.

${ }^{60}$ Ibidem, s. 3. [reakcja natychmiastowej ochrony] i Appraisal response [reakcja oceniająca] ${ }^{61}$. W konsekwencji, muzyczne oczekiwania i reakcje na nie przedstawia Huron jako całe spektrum zjawisk rozciągających się od prostych reakcji orientacyjnych, po złożone, oceniające procesy poznawcze. W przeciwieństwie do Meyera, Huron zdaje sobie sprawę, że mechanizmy predykcyjne oparte na wcześniejszym doświadczeniu muzycznym nie są jedyną możliwą przyczyną powstawania naszych reakcji emocjonalnych na muzykę i wskazuje, iż nasze oczekiwania słuchowe zawierają zarówno komponenty dziedziczne, jak i wyuczone ${ }^{62}$. Ważnym elementem, którego brakuje w propozycji Meyera, jest ponadto przyjęcie przez Hurona perspektywy ewolucyjnej celem uzasadnienia i wyjaśnienia zasadności wyróżnionych systemów poznawczych. Co ciekawe jednak, Huron odnosi swoje wyjaśnienia ewolucyjne do adaptacyjności wskazanych mechanizmów poznawczych jako ogólnych własności biologii człowieka i całkowicie pomija kwestie ewentualnej specyfiki zdolności poznawczych odpowiedzialnych za przetwarzanie bodźców muzycznych jako odrębnych zjawisk adaptacyjnych.

Zdaniem Hurona Meyerowi nie udało się odpowiedzieć na pytanie, dlaczego manipulowanie oczekiwaniami słuchacza względem jednego parametru muzycznego może prowadzić do doświadczania przez tego słuchacza przyjemności ${ }^{63}$ i to jej zróżnicowanych stanów. Mimo uwzględnienia wiedzy o uczeniu się statystycznym i wiedzy o mechanizmach neurobiologicznych związanych z predykcyjnym charakterem przetwarzania informacji, nie udało się też tego dokonać w sposób wyczerpujący Huronowi w jego Słodkich oczekiwaniach. Huron wprowadza wprawdzie w swojej koncepcji rozróżnienie na pięć różnych mechanizmów predykcyjnych, $\mathrm{z}$ których każdy może wywoływać różne stany emocjonalne, $\mathrm{w}$ tym także przyjemność. Istnieją też liczne propozycje teoretyczne, w których wskazuje się na wiele innych mechanizmów poznawczych odpowiedzialnych za reakcje emocjonalne na muzykę $e^{64}$. Żadna $z$ tych propozycji

61 Ibidem, s. 15

62 Ibidem, s. 62.

${ }^{63}$ D. Huron, Musical Aesthetics..., op. cit.

64 P.N. Juslin i in., How Does Music Evoke Emotions?, [w:] Handbook of Music and Emotion: Theory, Research, Applications, red. P.N. Juslin, J.A. Sloboda, London 2010, s. 605-642; P.N. Juslin, D. Västfjäll, 
nie wyjaśnia jednak, dlaczego niespełnianie niektórych oczekiwań dotyczących jednego tylko, wybranego parametru muzycznego, na przykład następstwa akordów, prowadzi do odczuwania przyjemności estetycznej, a niespełnianie innych oczekiwań względem tego samego parametru - nie. Mówiąc bardziej precyzyjnie, jednym z głównych problemów dla wszystkich tych teorii jest wyjaśnienie, dlaczego zaskoczenie spowodowane zmianą jednego parametru może powodować czasem szczególną przyjemność, a kiedy indziej co najwyżej rozbawienie czy wręcz rozczarowanie. Zarówno kadencja zwodnicza, oryginalny skok interwałowy, czy rzadkie następstwo harmoniczne, ale też zwykła pomyłka wykonawcy czy dźwięk obcy $\mathrm{w}$ przebiegu diatonicznym wiążą się z mniejszym lub większym zaskoczeniem, które, według postulatów Meyera i Hurona, może przybierać postać zróżnicowanych stanów psychicznych - może być większe lub mniejsze. Skoro w każdym z tych przypadków mamy do czynienia $\mathrm{z}$ różnym pod względem wartości zaskoczenia niespełnieniem oczekiwań, stany te można opisać w kategoriach prawdopodobieństwa, przypisując im różne wartości liczbowe. Są to jednak przeżycia jakościowo różne pod względem specyfiki doświadczeń emocjonalnych towarzyszących słuchaniu tych zjawisk. Mamy zatem z jednej strony jakościowo różne stany psychiczne, a $\mathrm{z}$ drugiej, jednowymiarową skalę prawdopodobieństwa wystąpienia danego dźwięku (wspomnianą tzw. zawartość informacyjną).

\section{NIEPEWNOŚĆ A ZASKOCZENIE}

Ciekawe rozwiązanie tego problemu zaproponowano ostatnio na gruncie interdyscyplinarnych badań łączących muzykologię z uczeniem maszynowym i neurobiologią ${ }^{65}$. Autorzy tej koncepcji postulują istnienie dwóch stanów oczekiwań tj. oczekiwań prospektywnych (w oryg. ang. prospective states of expectation), określanych także mianem niepewności (w oryg. ang.

Emotional Responses to Music: The Need to Consider Underlying Mechanisms, „The Behavioral and Brain Sciences” 2008 t. 31 nr 5, s. 559621; P.N. Juslin, Musical Emotions Explained..., op. cit.; J. Panksepp, G. Bernatzky, Emotional Sounds and the Brain: The Neuro-Affective Foundations of Musical Appreciation, „Behavioural Processes” 2002 t. 60 nr 2, s. 133-155.

${ }^{65}$ V. Cheung i in., Uncertainty and Surprise..., op. cit. uncertainty) oraz retrospektywnych (w oryg. ang. retrospective states of expectation), nazywanych tez zaskoczeniem (w oryg. ang. surprise). Choć nazwy tych dwóch różnych stanów oczekiwań mogą wydawać się niefortunne, w istocie odnoszą się do precyzyjnie określonych różnych sposobów kształtowania naszych oczekiwań. Niepewność jest stanem związanym ze stopniem przewidywalności tego, co nastąpi po określonym przebiegu ${ }^{66}$. Zaskoczenie natomiast odnosi się do stopnia odstępstwa tego, co nastąpi od tego, co przewidujemy ${ }^{67}$. W modelu tym oba stany stanowią odrębne zmienne, którym przypisać można różne wartości liczbowe, wykorzystując do tego celu uczenie maszynowe. Jak zaobserwowali autorzy wspomnianych badań, szczególnie przyjemne stany emocjonalne wywoływane doświadczeniem syntaktycznej struktury muzycznej (we wspomnianych badaniach posłużono się jako bazą danych następstwami 80.000 akordów zaczerpniętych $\mathrm{z}$ amerykańskiej muzyki popularnej) są skutkiem specyficznej interakcji pomiędzy stanami niepewności i zaskoczenia. Badania wskazują, że przyjemne doznania pojawiają się wówczas, gdy stan niepewności o dużej wartości liczbowej współwystępuje ze stanem zaskoczenia o niewielkiej wartości liczbowej oraz gdy stan niepewności o małej wartości liczbowej występuje razem z zaskoczeniem o dużej wartości liczbowej.

Dodatkowo badacze ci zaobserwowali, za pomocą badań neuroobrazowych z wykorzystaniem funkcjonalnego rezonansu magnetycznego, aktywność różnych struktur mózgowia powiązaną ze wspomnianymi

${ }^{66}$ Różne przebiegi muzyczne prowadzą do różnych stanów niepewności. W dużym uproszczeniu, przebieg kończący się dźwiękiem prowadzącym w kadencji wytwarza w nas mały stopień niepewności, podczas gdy następstwo dźwięków w serii dodekafonicznej prowadzi zwykle do dużej niepewności. Jest to związane z faktem, że prawdopodobieństwo wystąpienia każdego z dwunastu dźwięków systemu muzycznego po określonym przebiegu muzycznym jest zwykle różne. Kiedy różnice te są duże, a prawdopodobieństwo wystąpienia jednego z dźwięków systemu jest bardzo duże, jak ma to miejsce w przypadku następstwa po dźwięku prowadzącym, nasza niepewność jest niewielka, kiedy zaś różnice te są niewielkie (wartości prawdopodobieństwa wystąpienia wszystkich dźwięków systemu są zbliżone), jak dzieje się zwykle w przypadku następstw dźwięków w serii dodekafonicznej, nasza niepewność jest duża.

67 O ile niepewność wymaga uwzględnienia w naszych przewidywaniach wszystkich możliwych następstw, o tyle zaskoczenie odnosi się do zawartości informacyjnej konkretnego dźwięku (lub akordu), czyli tego, jakie jest prawdopodobieństwo wystąpienia tylko tego konkretnego dźwięku (lub akordu). 
stanami: innych dla niepewności (aktywność jądra półleżącego) oraz innych dla interakcji pomiędzy stanem niepewności i zaskoczenia (aktywność ciała migdałowatego, hipokampu i kory słuchowej ${ }^{68}$. Taka zaobserwowana dysocjacja aktywności struktur mózgowia wskazuje, że wprowadzone rozróżnienie na oczekiwania prospektywne i retrospektywne nie jest jedynie bytem abstrakcyjnym, wytworzonym w oparciu o uczenie się maszynowe, ale ma swoje odzwierciedlenie $w$ funkcjonowaniu mózgowia w odpowiedzi na bodźce muzyczne. Choć opisane tu badania i propozycje teoretyczne wydają się bardzo odległe od idei Meyera, w istocie są one bezpośrednią kontynuacją jego postulatów wyrażonych w Emocji $i$ znaczeniu $w$ muzyce. Bez pionierskich rozważań Meyera dotyczących roli oczekiwań $\mathrm{w}$ doświadczeniu muzyki nie byłoby z pewnością tak spektakularnego postępu w obszarze badań nad percepcją muzyki, jaki obserwujemy w ostatnich dziesięcioleciach. Wydaje się, że wskazany model (bądź jego rozbudowane wersje) może być podstawą do badań nie tylko nad przyjemnością, ale całą gamą różnych innych stanów afektywnych, charakteryzujących doświadczenie syntaktyki muzycznej, które określane są jako qualia tonalne ${ }^{69}$. Równie ciekawe w tym względzie może okazać się badanie doświadczeń syntaktyki opartej na zjawiskach metro-rytmicznych. Obiecujące mogą być też modele, które uwzględniałyby wartości stanów prospektywnych i retrospektywnych wyliczonych na podstawie elementów melicznych i metro-rytmicznych ujmowanych łącznie.

\section{POSTULATY MEYERA A SPÓR O ZNACZENIE MUZYKI}

Powiązanie konkretnych cech struktury muzycznej $\mathrm{z}$ reakcjami emocjonalnymi ludzi stało się dla Meyera ważkim argumentem dla ujmowania tych reakcji jako jednego, choć, co ważne, nie jedynego, $\mathrm{z}$ rodzajów znaczenia muzyki ${ }^{70}$. Łatwo nie zgodzić się $\mathrm{z}$ takim ujęciem, jeśli punktem odniesienia dla naszych rozważań byłoby znaczenie języka naturalnego, rozumiane jako jedno z wielu możliwych znaczeń, obecnych

\footnotetext{
${ }^{68}$ Ibidem.

${ }^{69}$ D. Huron, Sweet Anticipation..., op. cit.

${ }^{70}$ L.B. Meyer, Emocja..., op. cit., s. 12-13.
}

w komunikacji międzyludzkiej. Skoro to nieświadome uczenie się cech charakterystycznych stylów obecnych w kulturze muzycznej, w której żyjemy, prowadzi do określonych, intersubiektywnie podobnych (co najmniej w przypadku postulowanego przez Meyera słuchacza kompetentnego) reakcji emocjonalnych; reakcje te stanowią treść komunikatu muzycznego, podobnie jak znaczenie języka naturalnego jest skutkiem utajonego uczenia się gramatyki i leksykonu języka ojczystego. Co jednak chyba najistotniejsze, w sporze pomiędzy formalistami, absolutystami, emotywistami i referencjalistami Meyer w sposób jednoznaczny opowiadał się za traktowaniem znaczenia emotywnego jako wewnątrzmuzycznego, czyli, w jego ujęciu, bezpośrednio wynikającego $\mathrm{z}$ wywoływania u słuchacza emocji przez „związki muzyczne występujące w dziele sztuki" "11. Autor określał zatem swoją postawę jako emotywistyczno-absolutystyczną. Stanowisko to spotkało się z dużą krytyką, ponieważ, jak wskazywało wielu, Meyerowskie oczekiwania są w nas, a nie w muzyce ${ }^{72}$, co czyni Meyerowskie znaczenie pozamuzycznym wbrew deklaracjom samego Meyera.

Krytyka ta wydaje się jednak oparta na kardynalnym niezrozumieniu poglądów Meyera, dotyczących istoty tego, czym jest struktura muzyki. Oczywiście, jeśli założylibyśmy, że struktura muzyki jest zjawiskiem obiektywnie istniejącym poza podmiotem słuchającym muzyki, wskazane zastrzeżenia co do poglądów Meyera byłyby całkowicie zasadne. Wydaje się jednak, że Meyer nie podzielał takiego stanowiska na ontologię struktury muzycznej, wskazując na pokrewieństwo pomiędzy błędem uniwersalizmu i fizykalizmu. Jak pisał „[...] uniwersalistyczne ujęcie [reakcji na muzykę] jest pokrewne również szacownemu - ze względu na swój wiek - poszukiwaniu fizykalnego, quasi-akustycznego wyjaśnienia przeżycia muzycznego a więc usiłowaniu tłumaczenia komunikacji muzycznej w kategoriach drgań, stosunków interwałowych itp."73. Meyer sprzeciwiał się zatem powszechnym po dziś dzień poglądom neopitagorejskim w muzykologii,

\footnotetext{
71 Ibidem, s. 13.

72 Por. np. R.R. Dipert, Meyer's Emotion and Meaning in Music: A Sympathetic Critique of its Central Claims, „In Theory Only” 1983 t. 6 nr 8, s. 3-17; E. Dunsby, Explaining Meyer, „Music Analysis” 1983 t. 2 nr 2, s. 209-220.

${ }^{73}$ L.B. Meyer, Emocja..., op. cit., s. 16.
} 
które upatrują obiektywnego istnienia kodu muzycznego w świecie akustycznym ${ }^{74}$. Przeciwnie, powiązanie znaczenia emotywnego - reakcji emocjonalnej na strukturę muzyczną - $\mathrm{z}$ prawdopodobieństwem występowania poszczególnych dźwięków, które zależy od doświadczenia słuchacza, a więc jego stanów psychicznych, wskazuje, że stany te traktował Meyer, przynajmniej implicite, jako integralną część kodu muzycznego. $Z$ tej perspektywy nie można mówić zatem o Meyerowskich znaczeniach emotywnych muzyki jako znaczeniach pozamuzycznych.

Niestety w odniesieniu do zagadnień ontologicznych struktury muzycznej Meyer nie formułuje spójnego i klarownego stanowiska, pozostawiając te kwestie $\mathrm{w}$ sferze niedopowiedzianych sugestii. Być może wiąże się to z rodzącą się w czasach publikacji Emocji i znaczenia $w$ muzyce świadomością rozdźwięku pomiędzy wizją człowieka serwowaną z jednej strony przez przyrodników a z drugiej przez humanistów ${ }^{75}$. Świadomość ta prowokowała do ożywionych dyskusji, w których Meyer także uczestniczy ${ }^{76}$. Niezależnie jednak od tych dyskusji i faktycznego stanowiska Meyera w kwestii ontologii struktury muzyki, jego krytyka neopitagoreizmu w refleksji o muzyce, a w szczególności w odniesieniu do problematyki znaczenia muzyki, wskazuje na świadomość konsekwencji psychologizmu dla ontologii muzyki. Konsekwencje te są nie tylko istotne $\mathrm{z}$ punktu widzenia określenia faktycznego bytu struktury muzycznej i szerzej muzyki, ale pociągają za sobą też wiele interesujących pytań, na które nie ma jak dotąd jednoznacznych odpowiedzi. Po pierwsze, $\mathrm{w}$ jakim sensie reakcja emocjonalna na zmieniające się następstwa dźwiękowe jest zjawiskiem wewnątrzmuzycznym? Czy jest ona immanentną częścią struktury muzycznej i stanowi podstawę hierarchizacji dźwięków w strukturze syntaktycznej muzyki? Czy jest może jedynie skutkiem poznawczego rozpoznania tej hierarchii? $\mathrm{Z}$ jednej strony w sporze

\footnotetext{
74 P. Podlipniak, The Neo-Pythagorean View of Musical Structure in the Light of Music Psychology, „Roczniki Psychologiczne” 2020 t. 22 nr 2, s. 121-134; R. Parncutt, G. Hair, A Psychocultural Theory of Musical Interval: bye bye Pythagoras, „Music Perception: An Interdisciplinary Journal” 2018 t. $35 \mathrm{nr}$ 4, s. 475-501.

75 Ch.P. Snow, The Two Cultures, New York 1961; L. Ferry i J-D. Vincent, Co to jest człowiek?, przeł. M. Milewska, Warszawa 2003.

76 Por. G.S. Stent, L.B. Meyer, On Art and Science: A Reply to Leonard B. Meyer, „Critical Inquiry” 1975 t. 1 nr 3, s. 683-698.
}

tak zwanych kognitywistów z emotywistami ${ }^{77}$, dotyczącym charakteru przeżycia emocjonalnego muzyki, poglądy Meyera traktuje się jako reprezentujące postawę kognitywistów. Meyer wskazywał bowiem, że nasze reakcje emocjonalne na zmieniającą się strukturę muzyki są skutkiem wcześniejszego zrozumienia związków właściwych przebiegowi muzycznemu ${ }^{78}$. Z drugiej strony, Meyer próbował przeciwstawiać się tradycyjnej „dychotomii rozumu i emocji”, postulując traktowanie obu tych zjawisk jako różnych przejawów „tego samego procesu psychologicznego"79. Podkreślał, że afektywne i intelektualne reakcje na muzykę „zależą od tych samych procesów percepcyjnych"

Obecnie uważa się istotnie, że rozdzielenie procesów emocjonalnych i poznawczych jest niemożliwe tak z perspektywy neuropsychologicznej, jak i neurobiologicznej ${ }^{81}$. Wielu badaczy podkreśla jednak, że do zaistnienia reakcji emocjonalnej, często utożsamianej z aktywnością głównie struktur podkorowych mózgowia, na zmieniające się następstwa dźwięków w muzyce konieczne jest wcześniejsze przetworzenie tej informacji w strukturach korowych ${ }^{82}$. Takie ujęcie sugeruje $\mathrm{w}$ pewnym sensie rozdzielność rozpoznawania struktury muzycznej od reakcji emocjonalnej. Inni z kolei wskazują, że istotą przetwarzania złożonych bodźców syntaktycznych, w tym muzycznych, jest permanentna transformacja informacji $w$ tak zwanych pętlach korowo-podkorowych ${ }^{83}$, a to oznacza, że do prawidłowego rozpoznania danej struktury muzycznej konieczna jest aktywność zarówno

\footnotetext{
77 Emotywiści postulują, w przeciwieństwie do reprezentantów postawy kognitywistycznej, że część naszych reakcji emocjonalnych na muzykę ma charakter bezpośredni i nie wymaga wcześniejszych, odrębnych procesów poznawczych (por. C.L. Krumhansl, An Exploratory Study of Musical Emotions and Psychophysiology, „Canadian Journal of Experimental Psychology / Revue canadienne de psychologie experimentale" (grudzień 1997) t. $51 \mathrm{nr} 4$, s. 336-353.

${ }^{78}$ L.B. Meyer, Emocja..., op. cit., s. 13.

79 Ibidem, s. 56.

80 Ibidem.

81 J. Storbeck, G.L. Clore, On the Interdependence of Cognition and Emotion, „Cognition and Emotion” 2007 t. 21 nr 6, s. 1212-1237; A.R. Damasio, Błąd Kartezjusza: emocje, rozum i ludzki mózg, przeł. M. Karpiński, Poznań 2011.

82 S. Koelsch i in., Processing of Hierarchical Syntactic Structure in Music, „Proceedings of the National Academy of Sciences of the United States of America” 2013 t. 110 nr 38, s. 15 443-15 448; B. Maess i in., Musical Syntax Is Processed in Broca's Area: an MEG Study, „Nature Neuroscience” 2001 t. 4 nr 5, s. 540-545.

83 E.J. Gorzelańczyk i in., Pitch Syntax Violations..., op. cit.
} 
struktur korowych, jak i podkorowych. Innymi słowy, warunkiem koniecznym przetwarzania na przykład syntaktyki muzycznej wysokości dźwięku jest aktywność podkorowa jako część odrębnego układu, który wyewoluował dzięki specyficznej presji selekcyjnej ${ }^{84}$. Jeśli uznamy, że własnością przetwarzania syntaktyki języka naturalnego jest mapowanie jej na znaczenia leksykalne $e^{85}$, to przetwarzanie syntaktyki muzycznej polega na mapowaniu na doznania emocjonalne ${ }^{86}$. Pogląd taki jest zatem zgodny z postulatami Meyera o wewnątrzmuzycznym charakterze znaczeń emotywnych muzyki. Podkreślić należy jednak, że, w świetle dzisiejszej wiedzy, wskazywane przez Meyera znaczenia emotywne nie wyczerpują całego spektrum możliwych reakcji emocjonalnych na muzykę.

\section{PODSUMOWANIE}

Doniosłości Emocji i znaczenia w muzyce Meyera dla ówczesnej, ale i obecnej refleksji o muzyce można upatrywać co najmniej w dwóch ważnych, podstawowych, ogólnych założeniach, na których skonstruowana jest ta praca. Pierwsze $z$ nich dotyczy postulatu uprawiania badań interdyscyplinarnych celem pełnego zrozumienia zjawisk rządzących doświadczeniem muzyki. Interdyscyplinarność, której niemal wzorcowym przykładem jest podejście Meyera w Emocji i znaczeniu w muzyce, polega nie tylko na wykorzystaniu perspektyw charakterystycznych dla różnych dyscyplin naukowych, ale przede wszystkim na ustaleniu wspólnego paradygmatu dla podejmowanych badań interdyscyplinarnych. Dziś, kiedy coraz więcej wyników badań przekonuje nas o neurobiologicznych podstawach wszelkich czynności poznawczych człowieka, takim paradygmatem jest niewątpliwie naturalizm i związany $\mathrm{z}$ nim redukcjonizm obowiązujący od dawna $\mathrm{w}$ naukach przyrodniczych. Drugim założeniem Meyera, które oddziaływało i oddziałuje na refleksję o muzyce, jest przekonanie

${ }^{84}$ P. Podlipniak, The Evolutionary Origin of Pitch Centre Recognition, „Psychology of Music” 2016 t. 44 nr 3, s. 527-543; P. Podlipniak, The Role of the Baldwin Effect in the Evolution of Human Musicality, „Frontiers in Neuroscience” October 2017 t. 11, s. 542.

${ }^{85}$ D. Bickerton, Syntax for Non-Syntacticians. A Brief Primer, [w:] Biological Foundations and Origin of Syntax, red. D. Bickerton, E. Szathmáry, Cambridge, MA-London 2009, s. 3-13.

${ }^{86}$ P. Podlipniak, Pitch Syntax as an Evolutionary Prelingual Innovation, „Musicae Scientiae” 2020, 102986492094155. o istotnym udziale psychiki człowieka we współtworzeniu fenomenu nazywanego muzyką. Choć idea ta nie jest, jak się wydaje, wciąż powszechna w muzykologii analitycznej i historycznej, dla naturalistycznie zorientowanej muzykologii systematycznej jest już niemal „aksjomatem”. Nie do przecenienia pozostaje też wpływ Emocji i znaczenia na wąsko rozumiany obszar badań nad muzyką i emocjami. Książka ta stała się wręcz swoistą mapą drogową dla tego obszaru badań. Sloboda na przykład podkreśla kluczową rolę dla swoich badań dwóch obserwacji Meyera, tj. definiowania charakterystyki emocjonalnej reakcji na muzykę poprzez ścisłe powiązanie tej reakcji ze zmieniającą się $\mathrm{w}$ czasie strukturą przebiegu muzycznego oraz powiązania emocji muzycznych z poznawczymi procesami tworzenia i weryfikowania przewidywań następstw dźwięków w muzyce ${ }^{87}$.

Niewątpliwym mankamentem pierwotnych poglądów Meyera na naturę związku muzyki z emocjami było jego przekonanie o wyłączności postulowanego przez niego mechanizmu psychicznego w wytwarzaniu reakcji emocjonalnej słuchacza na przebieg muzyczny. Meyer twierdził wprost, że „[...] strukturę afektywnej reakcji na utwór muzyczny można zgłębić przez badanie samej muzyki”"8s. Chęć wyjaśnienia całokształtu doświadczenia emocjonalnego muzyki za pomocą jednej spójnej teorii była jednak podówczas charakterystyczna dla dyskursu muzykologicznego. Konsekwencją przyjęcia przez Meyera takiego stanowiska było całkowite odrzucenie przez niego możliwości istnienia naturalnych, wspólnych gatunkowo wszystkim ludziom i niezależnych od enkulturacji reakcji na muzykę. Meyer określał wszelkie tego typu poglądy jako obarczone „błędem uniwersalizmu”, który polega jego zdaniem na „[...] przeświadczeniu, że reakcje uzyskane eksperymentalnie lub w inny sposób są uniwersalne, naturalne i ko-

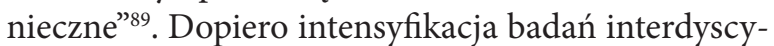
plinarnych w obszarze muzykologii systematycznej, uwzględniającej osiągnięcia neurobiologii i biologii ewolucyjnej wraz z postępem badawczym, jaki dokonał się w naukach przyrodniczych schyłku dwudziestego wieku, uświadomiły badaczom, że złożoności ludzkiej reakcji emocjonalnej na muzykę nie da się

\footnotetext{
87 J. Sloboda, Leonard Meyer: Embracing Uncertainty..., op. cit.

${ }^{88}$ L.B. Meyer, Emocja..., op. cit., s. 47.

89 Ibidem, s. 16.
} 
wyjaśnić za pomocą jednego mechanizmu psychicznego, ale konieczne jest do tego uwzględnienie wielu mechanizmów o zróżnicowanym wieku ewolucyjnym i funkcjach, także tych, które prowadzą do reakcji o charakterze uniwersalnym ${ }^{90}$.

Inną słabością założeń Meyerowskich, która zdaje się towarzyszyć także współczesnym badaczom podejmującym zagadnienia percepcji muzyki z perspektywy proksymalnej ${ }^{91}$, jest przekonanie o niespecyficzności muzycznej mechanizmu psychicznego odpowiedzialnego za reakcję emocjonalną w odpowiedzi na doświadczenie zmieniającej się struktury wysokościowej i metro-rytmicznej muzyki. Postulowanie ogólnego mechanizmu psychicznego jako systemu warunkującego doświadczenie emocjonalne muzyki nie wyjaśnia bowiem obserwowanej psychicznej i behawioralnej specyfiki tego doświadczenia na tle innych zjawisk percepcyjnych. Jednym z proponowanych wyjaśnień tej różnicy jest wskazanie na dynamiczny charakter muzyki w porównaniu np. ze statycznym charakterem doświadczenia malarstwa ${ }^{92}$. Innym rozwiązaniem tej kwestii jest wskazywanie na różnice pomiędzy modalnościami słuchową i wzrokową ${ }^{93}$. W obu przypadkach poważnym problemem pozostaje jednak wyraźna różnica pomiędzy doświadczeniem emocjonalnym struktury dźwiękowej przebiegu muzycznego i mowy. Jeśli, z jednej strony zarówno mowa, jak i muzyka są adaptacjami, a $\mathrm{z}$ drugiej strony mowa, a dokładniej syntaktyka języka naturalnego, jest zjawiskiem funkcjonalnie i filogenetycznie odrębnym od syntaktyki (lub syntaktyk tj. syntaktyki wysokości dźwięku i syntaktyki metro-rytmicznej) muzycznej, to możliwe jest, że przetwarzanie syntaktyki mowy wiąże się $\mathrm{z}$ aktywnością odrębnego mechanizmu poznawczego związanego z odrębną siecią neuronalną od mechanizmu (lub mechanizmów) odpowiedzialnego za przetwarzanie syntaktyki muzycznej ${ }^{94}$.

${ }_{90}$ P.N. Juslin i in., How Does Music Evoke Emotions?..., op. cit.; P.N. Juslin, D. Västfjäll, Emotional Responses to Music..., op. cit.; J. Panksepp, G. Bernatzky, Emotional Sounds..., op. cit.; E.J. Gorzelańczyk, P. Podlipniak, Human Singing as a Form of Bio-Communication, „Bio-Algorithms and Med-Systems” 2011 t. 7 nr 2, s. 79-83.

${ }_{91}$ D. Huron, Musical Aesthetics..., op. cit.; D. Huron, Sweet Anticipation..., op. cit.; C.L. Krumhansl, Cognitive Foundations of Musical Pitch, New York 1990.

92 V. Cheung i in., Uncertainty and Surprise..., op. cit.

${ }_{93}$ J. Panksepp, G. Bernatzky, Emotional Sounds..., op. cit.

${ }^{94}$ P. Podlipniak, Pitch syntax..., op. cit.
Stosunkowo mało zagospodarowanym obszarem badawczym naturalistycznie zorientowanej muzykologii systematycznej, w którym nie sposób nie dostrzec dalekosiężnych wpływów idei Meyerowskich, zwłaszcza tych wykorzystujących teorię informacji do rozważań nad stylem muzycznym, jest, wyodrębniająca się ostatnio nieśmiało w ramach neuroestetyki, neuroestetyka muzyki. Poglądy Meyera przywoływane są $\mathrm{w}$ jej ramach głównie $\mathrm{z}$ uwagi na wykorzystanie przez niego kategorii psychologicznych dla rozważań teoretyczno-muzycznych. Elvira Brattico i Marcus Pearce wskazują Emocje i znaczenie w muzyce jako przykład podejścia kontrastującego z postulatami głoszącymi niemożność wykorzystania wiedzy psychologicznej i neurobiologicznej do rozstrzygania kwestii estetycznych $^{95}$. Zwykle jednak w rozważaniach, których autorzy deklarują neuroestetykę muzyki jako przedmiot podejmowanej refleksji, bądź to podkreśla się rolę Meyerowskich oczekiwań w powstawaniu doświadczenia estetycznego ${ }^{96}$, bądź wskazuje się na wagę wykorzystania przez Meyera praw psychologii postaci dla celu wyjaśnienia integracyjnych mechanizmów w doświadczeniu muzyki ${ }^{97}$. Dotychczasowe prace opatrzone określeniem „neuroestetyka muzyki” nie różnią się pod względem metodologicznym od innych subdyscyplin naturalistycznie zorientowanej muzykologii systematycznej, takich jak biomuzykologia, psychologia poznawcza muzyki, czy neuropsychologia muzyki ${ }^{98}$, dlatego wpływ Emocji i znaczenia w muzyce na tę nową, rodzącą się subdyscyplinę muzykologii jest równie ważny, jak w przypadku psychologii muzyki. Rosnące oczekiwania budzi natomiast wpływ naturalizmu obecnego w neuroestetyce na refleksję estetyczną w muzykologii. Można spodziewać się, że wraz ze wzrostem znaczenia takiego podejścia w estetyce postulaty Meyera będą odgrywały coraz większą rolę.

${ }_{95}$ E. Brattico, M. Pearce, The Neuroaesthetics of Music, „Psychology of Aesthetics, Creativity, and the Arts" February 2013 t. 7 nr 1, s. $48-61$.

${ }^{96}$ E. Brattico, B. Bogert, T. Jacobsen, Toward a Neural Chronometry for the Aesthetic Experience of Music, „Frontiers in Psychology” 2013 t. 4, s. 206.

${ }_{97}$ P. Brattico, E. Brattico, P. Vuust, Global Sensory Qualities and Aesthetic Experience in Music, „Frontiers in Neuroscience” 2017.

98 P. Podlipniak, P. Przybysz, Sztuka, mózg, muzyka: perspektywy neuroestetyki muzyki, [w:] Neuroestetyka muzyki, red. M. Bogucki i in., Poznań 2013, s. 11-38.

\section{3}


Przedstawione powyżej przykłady dalekosiężnego wpływu idei wyrażonych w Emocji i znaczeniu na muzykologię systematyczną zorientowaną naturalistycznie dokumentują oczywiście jedynie niewielką część prac, dla których myśl Meyera stanowiła i stanowi źródło inspiracji i wyzwań poznawczych. Nie sposób przewidzieć, $w$ jakich jeszcze obszarach badawczych rozważania skierowane zostaną $\mathrm{w}$ stronę poglądów jednego z wybitniejszych teoretyków muzyki dwudziestego wieku. Nie ulega jednak wątpliwości, że Emocja $i$ znaczenie $w$ muzyce należy do tych nielicznych prac, które przyczyniły się w sposób zasadniczy do rozwoju naturalistycznie zorientowanych nauk o muzyce.

\section{BIBLIOGRAFIA}

Bannan Nicholas, Every Child a Composer: Music Education in an Evolutionary Perspective, Peter Lang, Bern-New York 2019.

Beveridge Lowell P., Review: Emotion and Meaning in Music by Leonard B. Meyer, „The Christian Scholar” 1958 t. 41, s. $175-178$.

Bharucha Jamshed J., Expectation as an Implicit Process, „Music Perception: An Interdisciplinary Journal” 2008 t. 25 nr 5, s. $477-478$.

Bharucha Jamshed J., Music Cognition and Perceptual Facilitation: A Connectionist Framework, „Music Perception” 1987 t. 5 nr 1, s. 1-30.

Bharucha Jamshed J., Tonality and Expectation, [w:] Musical Perceptions, red. Rita Aiello, John A. Sloboda, Oxford University Press, New York 1994, s. 213-239.

Bickerton Derek, Syntax for Non-Syntacticians. A Brief Primer, [w:] Biological Foundations and Origin of Syntax, red. Derek Bickerton, Eörs Szathmáry, MIT Press, Cambridge, MA-London 2009, s. 3-13.

Brattico Elvira, Bogert Brigitte, Jacobsen Thomas, Toward a Neural Chronometry for the Aesthetic Experience of $\mathrm{Mu}$ sic, „Frontiers in Psychology” 2013 t. 4, s. 206.

Brattico Pauli, Brattico Elvira, Vuust Peter, Global Sensory Qualities and Aesthetic Experience in Music, „Frontiers in Neuroscience" 2017.

Brattico Elvira, Pearce Marcus, The Neuroaesthetics of Music, „Psychology of Aesthetics, Creativity, and the Arts” February 2013 t. 7 nr 1, s. 48-61.

Bray Natasha, Musical Pleasure Lies in Surprise, „Nature Reviews Neuroscience" 2020 t. 21 nr 1, s. 3.
Byros Vasili, Meyer's Anvil: Revisiting the Schema Concept, „Music Analysis” 2012 t. 31, s. 273-346.

Cheung Vincent K.M., Harrison Peter M.C., Meyer Lars, Pearce Marcus T., Haynes John Dylan, Koelsch Stefan, Uncertainty and Surprise Jointly Predict Musical Pleasure and Amygdala, Hippocampus, and Auditory Cortex Activity, „Current Biology” 2019 t. 29 nr 23, s. 4084-4092.e4.

Cook Nicholas, Przewodnik po analizie muzycznej, przeł. Stanisław Będkowski, Musica Iagellonica, Kraków 2014.

Cuddy Lola L., Tributes to Leonard B. Meyer: Editor's Introduction, „Music Perception: An Interdisciplinary Journal” 2008 t. 25 nr 5, s. 477.

Damasio Antonio R., Bład Kartezjusza: emocje, rozum i ludzki mózg przeł. Maciej Karpiński, Dom Wydawniczy „Rebis”, Poznań 2011.

Dipert Randall R., Meyer's Emotion and Meaning in Music: A Sympathetic Critique of its Central Claims, „In Theory Only" 1983 t. 6 nr 8, s. 3-17.

Dowling W. Jay, Harwood Dane L., Music Cognition, Academic Press, Orlando, San Diego 1986.

Dunsby Esther, Explaining Meyer, „Music Analysis” 1983 t. 2 nr 2, s. 209-220.

Dunsby Jonathan, Whittall Arnold, Music Analysis in Theory and Practice, Yale University Press, New Haven 1988.

Eschrich Susann, Münte Thomas F., Altenmüller Eckart O., Unforgettable Film Music: The Role of Emotion in Episodic Long-Term Memory for Music, „BMC Neuroscience” 2008 t. 9 nr 1, s. 48 .

Ferry Luc, Vincent Jean-Didier, Co to jest człowiek przeł. Monika Milewska, Państwowy Instytut Wydawniczy, Warszawa 2003.

Gorzelańczyk Edward J., Podlipniak Piotr, Human Singing as a Form of Bio-Communication, „Bio-Algorithms and Med-Systems" 2011 t. 7 nr 2, s. 79-83.

Gorzelańczyk Edward J., Podlipniak Piotr, Walecki Piotr, Karpiński Maciej, Tarnowska Emilia, Pitch Syntax Violations Are Linked to Greater Skin Conductance Changes, Relative to Timbral Violations - The Predictive Role of the Reward System in Perspective of Cortico-Subcortical Loops, „Frontiers in Psychology” April 2017 t. 8, s. 586 .

Guo Shuang, Koelsch Stefan, Effects of Veridical Expectations on Syntax Processing in Music: Event-Related Potential Evidence, „Scientific Reports” 2016 t. 6 nr 1, s. 19064.

Hansen Niels Chr., Pearce Marcus T., Predictive Uncertainty in Auditory Sequence Processing, „Frontiers in Psychology” September 2014 t. 5, s. 1052. 
Helmholtz Hermann von, On the Sensations of Tone as a Physiological Basis for the Theory of Music, przel. Alexander J. Ellis, wyd. 3., Aberdeen University Press, London-New York 1895.

Huron David B., Musical Aesthetics: Uncertainty and Surprise Enhance Our Enjoyment of Music, „Current Biology” 2019 t. 29 nr 23, R1238-40.

Huron David B., Sweet Anticipation: Music and the Psychology of Expectation, MIT Press, Cambridge, MA-London 2006.

Juslin Patrik N., Musical Emotions Explained: Unlocking the Secrets of Musical Affect, Oxford University Press, Oxford 2019.

Juslin Patrik N., Liljeström Simon, Västfäll Daniel, Lundqvist Lars-Olov, How Does Music Evoke Emotions?, [w:] Handbook of Music and Emotion: Theory, Research, Applications, red. Patrik N. Juslin, John A. Sloboda, Oxford University Press, London 2010, s. 605-642.

Juslin Patrik N., Västfjäll Daniel, Emotional Responses to Music: the Need to Consider Underlying Mechanisms, „The Behavioral and Brain Sciences" 2008 t. 31 nr 5, s. 559-621.

Ketchum John Davidson, Review of Emotion and Meaning in Music, „Canadian Journal of Psychology/Revue canadienne de psychologie” 1957 t. 11 nr 4, s. 264-266.

Koelsch Stefan, Rohrmeier Martin, Torrecuso Renzo, Jentschke Sebastian, Processing of Hierarchical Syntactic Structure in Music, „Proceedings of the National Academy of Sciences of the United States of America" 2013 t. 110 nr 38, s. 15443-15448.

Koelsch Stefan, Vuust Peter, Friston Karl, Predictive Processes and the Peculiar Case of Music, „Trends in Cognitive Sciences" 2019 t. 23 nr 1, s. 63-77.

Krumhansl Carol L., An Exploratory Study of Musical Emotions and Psychophysiology, „Canadian Journal of Experimental Psychology/Revue canadienne de psychologie experimentale" December 1997 t. 51 nr 4, s. 336-53.

Krumhansl Carol L., Cognitive Foundations of Musical Pitch, Oxford University Press, New York 1990.

Krumhansl Carol L., Leonard Meyer's Invitation to Cognitive Science, „Music Perception: An Interdisciplinary Journal” 2008 t. 25 nr 5, s. 482-483.

Lerdahl Fred, Composition and Cognition: Reflections on Contemporary Music and the Musical Mind, University of California Press, Oakland 2020.

Lerdahl Fred, Reflections on Leonard Meyer, „Music Perception: An Interdisciplinary Journal” 2008 t. 25 nr 5, s. $483-484$.
Lerdahl Fred, Jackendoff Ray, A Generative Theory of Tonal Music, MIT Press, Cambridge, MA-London 1983.

Llinás Rodolfo Riascos, I of the Vortex: From Neurons to Self, MIT Press, Cambridge, MA-London 2001.

Maess Burkhard, Koelsch Stefan, Gunter Thomas C., Friederici Angela D., Musical Syntax Is Processed in Broca's Area: an MEG Study, „Nature Neuroscience” 2001 t. 4 nr 5, s. $540-545$.

Margulis Elizabeth H., On Repeat: How Music Plays the Mind, Oxford University Press, Oxford-New York 2014.

Margulis Elizabeth H., Surprise and Listening Ahead: Analytic Engagements with Musical Tendencies, „Music Theory Spectrum" 2007 t. 29 nr 2, s. 197-217.

McAllester David P., Emotion and Meaning in Music. Leonard B. Meyer, "American Anthropologist” 1957 t. 59 nr 5, s. 940.

Meyer Leonard B., Emocja i znaczenie w muzyce, przeł. Antoni Buchner i Karol Berger, PWM, Kraków 1973.

Meyer Leonard B., Emotion and Meaning in Music, University of Chicago Press, Chicago 1956.

Meyer Leonard B., Explaining Music: Essays and Explorations, University of California Press, Berkeley-Los Angeles 1973.

Meyer Leonard B., Meaning in Music and Information Theory, „Journal of Aesthetics \& Art Criticism” 1957 t. 15, s. $412-24$.

Meyer Leonard B., Music, the Arts, and Ideas: Patterns and Predictions in Twentieth-Century Culture, University of Chicago Press, Chicago 1967.

Meyer Leonard B., Music and Emotion: Distinction and Uncertainties, [w:] Music and Emotion: Theory and Research, red. Patrik N. Juslin, John A. Sloboda, "Series in Affective Science”, Oxford University Press, Oxford 2001, s. 341-360.

Moss Fabian C., Neuwirth Markus, Harasim Daniel, Rohrmeier Martin, Statistical Characteristics of Tonal Harmony: A Corpus Study of Beethoven's String Quartets, „PLOS ONE” 2019 t. 14 nr 6. e0217242.

Narmour Eugene, The Analysis and Cognition of Basic Melodic Structures: The Implication-Realization Model, University of Chicago Press, Chicago 1990.

Newport Elissa L., Hauser Marc D., Spaepen Geertrui, Aslin Richard N., Learning at a Distance II. Statistical Learning of Non-Adjacent Dependencies in a Non-Human Primate, „Cognitive Psychology” 2004 t. 49 nr 2, s. 85-117.

Ockelford Adam, Comparing Notes: How We Make Sense of Music, Profile Books, London 2018. 
Panksepp Jaak, Bernatzky Günther, Emotional Sounds and the Brain: The Neuro-Affective Foundations of Musical Appreciation, „Behavioural Processes” 2002 t. 60 nr 2, s. 133-55.

Parncutt Richard, Hair Graham, A Psychocultural Theory of Musical Interval: Bye bye Pythagoras, „Music Perception: An Interdisciplinary Journal” 2018 t. 35 nr 4, s. 475-501.

Pearce Marcus T., Ruiz María H., Kapasi Selina, Wiggins Geraint A., Bhattacharya Joydeep, Unsupervised Statistical Learning Underpins Computational, Behavioural, and Neural Manifestations of Musical Expectation, „NeuroImage" March 2010 t. 50 nr 1, s. 302-13.

Pearce Marcus T., Wiggins Geraint A., Auditory Expectation: The Information Dynamics of Music Perception and Cognition, „Topics in Cognitive Science” 2012 t. 4 nr 4, s. $625-52$.

Pearce Marcus T., Wiggins Geraint A., Expectation in Melody: The Influence of Context and Learning, „Music Perception: An Interdisciplinary Journal" 2006 t. 23 nr 5, s. 377-405.

Podlipniak Piotr, Pitch Syntax as an Evolutionary Prelingual Innovation, „Musicae Scientiae” 2020, 102986492094155.

Podlipniak Piotr, The Evolutionary Origin of Pitch Centre Recognition, „Psychology of Music” 2016 t. 44 nr 3, s. 527-43.

Podlipniak Piotr, The Neo-Pythagorean View of Musical Structure in the Light of Music Psychology, „Roczniki Psychologiczne" 2020 t. 22 nr 2, s. 121-34.

Podlipniak Piotr, The Role of the Baldwin Effect in the Evolution of Human Musicality, „Frontiers in Neuroscience” October 2017 t. 11, s. 542.

Podlipniak Piotr, Przybysz Piotr, Sztuka, mózg, muzyka: perspektywy neuroestetyki muzyki, [w:] Neuroestetyka mu$z y k i$, red. Marcin Bogucki, Adrian Foltyn, Piotr Podlipniak, Piotr Przybysz, Hanna Winiszewska, Wydawnictwo PTPN, Poznań 2013, s. 11-38.

Rohrmeier Martin A., Koelsch Stefan, Predictive Information Processing in Music Cognition. A Critical Review, „International Journal of Psychophysiology” 2012 t. 83 nr 2, s. $164-75$.

Santolin Chiara, Saffran Jenny R., Constraints on Statistical Learning Across Species, „Trends in Cognitive Sciences” 2018 t. 22 nr 1, s. 52-63.

Schubert Emery, Pearce Marcus, A New Look at Musical Expectancy: The Veridical Versus the General in the Mental Organization of Music, [w:] International Symposium on Computer Music Multidisciplinary Research CMMR 2015: Music, Mind, and Embodiment, red. Richard Kronland -Martinet, Mitsuko Aramaki, Sølvi Ystad, Springer International Publishing, Cham 2016, s. 358-70.
Sherburne Donald W., Meaning and Music, „The Journal of Aesthetics and Art Criticism" 1966 t. 24 nr 4, s. 579-83.

Sloboda John A., Leonard Meyer: Embracing Uncertainty, „Music Perception: An Interdisciplinary Journal” 2008 t. $25 \mathrm{nr}$ 5, s. 489-91.

Sloboda John A., The Musical Mind, Oxford University Press, Oxford 1986.

Snow Charles P., The Two Cultures, Cambridge University Press, New York 1961.

Stent Gunther S., Meyer Leonard B., On Art and Science: A Reply to Leonard B. Meyer, „Critical Inquiry” 1975 t. 1 nr 3, s. 683-98.

Storbeck Justin, Clore Gerald L., On the Interdependence of Cognition and Emotion, „Cognition and Emotion” 2007 t. $21 \mathrm{nr} 6$, s. 1212-1237.

Temperley David, The Cognition of Basic Musical Structures, MIT Press, Cambridge, MA-London 2001.

Tillmann Barbara, Bigand Emmanuel, Musical Structure Processing after Repeated Listening: Schematic Expectations Resist Veridical Expectations, „Musicae Scientiae” September 1, 2010 t. $14 \mathrm{nr} 2$ suppl., s. 33-47.

Titchener John M., Broyles Michael E., Meyer, Meaning, and Music, „The Journal of Aesthetics and Art Criticism” 1973 t. $32 \mathrm{nr} 1$, s. 17.

Wittgenstein Ludwig J. J., Lectures and Conversations on Aesthetics, Psychology and Religious Belief, red. Cyril Barrett, University of California Press, Berkeley-Los Angeles 1967.

\section{SUMMARY}

\section{Piotr Podlipniak}

\section{Naturalistic Systematic Musicology and Meyer's Views on Emotions and Meaning in Music}

Leonard B. Meyer's book Emotion and Meaning in Music was published more than half a century ago. It still provides inspiration for musicologists with various specialisms to undertake research aimed at understanding the intriguing link between music and emotions and the relationship between musical structure and meaning. Since the publication of this outstanding volume we have seen extraordinarily dynamic development of the musicological disciplines constituting that part of systematic musicology which is based on the premises of naturalism. The article focuses on those selected research areas of this 
branch of musicology where the influence of the ideas first presented in the above volume is particularly significant. The most important of Meyer's postulates in naturalistically oriented systematic musicology that continue to be discussed include: the key role of expectation in shaping our emotional reactions to the musical passages we hear and the inner musical character of the affective meanings created in this way. The main challenges faced by Meyer's postulates during the recent decades are examined, and the solutions to them proposed within the framework of naturalistically oriented thinking about music.

\section{Keywords}

schematic expectations, veridical expectations, musical style, paradox of the information theory, Bayesian inference, uncertainty, surprisal, formalism, absolutism, emotivism, referentialism, neopythagoreanism 